Disponível em

ANEAD http://www.anpad.org.br/rac

RAC, Rio de Janeiro, v. 18, n. 2, art. 6, pp. 217-235, Mar./Abr. 2014

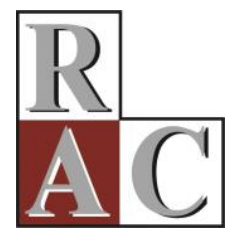

(oc) EY-No

\title{
Information Technology Investments and Supply Chain Governance
}

Pietro Cunha Dolci E-mail: pcdolci@gmail.com Universidade de Santa Cruz do Sul - UNISC UNISC, Av. Independência, 2293, 96815-900, Santa Cruz do Sul, RS, Brasil.

Antonio Carlos Gastaud Maçada

E-mail: acgmacada@ea.ufrgs.br Universidade Federal do Rio Grande do Sul - UFRGS UFRGS, Rua Washington Luiz, 855, 90010-460, Porto Alegre, RS, Brasil. 


\title{
Resumo
}

O objetivo dessa pesquisa é propor um modelo relacionando os investimentos em tecnologia da informação (TI), a governança da cadeia de suprimentos (GCS) e o seu desempenho. Foi realizado um estudo piloto com uma etapa qualitativa e outra quantitativa para a elaboração e o refinamento do instrumento. $\mathrm{Na}$ etapa qualitativa, foi elaborado um modelo baseado numa extensa revisão da literatura e em dois estudos de caso realizados em 6 grandes empresas brasileiras com relevância mundial. A partir dessa etapa, foi proposto um modelo que foi refinado através de uma etapa quantitativa com 38 executivos de grandes empresas. Foi identificado que a TI é um dos principais direcionadores da GCS, influenciando o desempenho das empresas na cadeia. O modelo final é composto por 5 constructos e 26 elementos. Nos constructos: (a) governança contratual, o elemento contrato formal emergiu das análises; (b) governança relacional, o elemento cooperação não foi confirmado; e (c) governança transacional: a transparência nas transações foi considerada como sendo um elemento importante. No constructo investimento em TI relacionado à GCS, emergiram cinco novos elementos. No constructo desempenho da cadeia relacionado com a GCS, foram destacados os aspectos de mercado como sendo relevantes. Assim, o modelo contempla elementos a serem analisados para entender como os investimentos em TI influenciam a GCS e seu desempenho.

Palavras-chave: investimentos em TI; governança da cadeia de suprimentos; desempenho da cadeia de suprimentos.

\begin{abstract}
The aim of this research is to propose a model that relates information technology (IT) investments, supply chain governance (SCG) and performance together. For this purpose, a pilot study involving both a qualitative and a quantitative stage was conducted. The qualitative analysis, consisting of an extensive literature review and two case studies conducted in six major, globally-relevant Brazilian companies, led to the development of an initial model. This model was refined during the quantitative stage that involved 38 executives from large national companies. IT was found to be one of the main drivers of SCG influencing companies' supply chain performance. The final model consists of 5 constructs and 26 elements. Regarding the SCG constructs: (a) a new element 'formal contracts', emerged in the 'contractual SCG' construct; (b) the element 'cooperation' was not confirmed in the 'relational SCG' construct; (c) the element 'transparency' was considered an important element in the 'transactional SCG' construct. Five new elements emerged in the 'IT investment' construct. Market aspects were highlighted as being relevant in the 'supply chain performance' construct. Thus, the model includes elements that can be analyzed in order to shed light on how IT investments influence SCG and supply chain performance.
\end{abstract}

Key words: IT investments; supply chain governance; supply chain performance. 


\section{Introduction}

The continued success and development of a supply chain is directly dependent on the information technology (IT) used by companies (D. F. Ross, 2011). The introduction of IT into business operations is drastically changing the way supply chains work, improving collaboration, trust and commitment among chain members (Ghiassi \& Spera, 2003).

The use of IT in supply chains goes beyond the operational aspects, which have been considered in several studies of supply chains (Ketchen \& Hult, 2007). In recent years, supply chain governance (SCG), which is seen as a means of analyzing inter-organizational relations as a multidimensional phenomenon manifested in the structures and processes of companies, has attracted growing academic attention (Jain \& Dubey, 2005). In addition, this topic includes more elements than those discussed in supply chain management alone.

Several studies have examined IT in supply chain management (Zhang, Donk, \& Vaart, 2011), but few studies have looked at IT in relation to SCG (Bitran, Gurumurthi, \& Sam, 2006; Ghosh \& Fedorowicz, 2008). Thus, studies and models are needed to measure the ways in which IT influences SGC.

According to Gunasekaran and Ngai (2012) the supply chain, supported by information technology, has a great influence on business performance. However, although there are a number of supply chain performance indicators, there is little consensus regarding what determines the performance of such chains (Aramyan, Ondersteijn, Kooten, \& Lansink, 2006). Moreover, no studies were found that evaluate the influence of SCG on supply chain performance, a topic that has been gaining attention in recent studies. Therefore, the aim of this study is to propose a model that links IT investments and supply chain governance and performance.

To this end, a pilot study was conducted in two stages, one qualitative and the other quantitative. The purpose of the former was to produce a model based on an extensive literature review and two case studies conducted in six large, globally-relevant Brazilian companies. The latter, quantitative stage involving 38 executives from large national companies, was designed to refine this model by adapting the refinement process suggested by Koufteros (1999). The next section explains how the initial model was constructed.

\section{Constructing the Model}

The method used to identify SCG studies consisted of three steps (Melville, Kraemer, \& Gurbaxani, 2004; Webster \& Watson, 2002). Firstly, an extensive literature review, with no time restriction, was undertaken on different databases (Emerald, Ebsco, ISI Web of Knowledge and Science Direct) and Google Scholar to find articles related to SCG. The following English and Portuguese keywords were used in the search: supply chain governance, governança da cadeia de suprimento, inter-organizational governance and governança interorganizacional. Secondly, citations from the identified articles were used as additional sources.

To date, we have found 65 articles in Ebsco, 24 in Science Direct, 22 in Emerald, 13 in in the ISI Web of Knowledge and 8 in Google Scholar, totaling 134 published between 1999 and 2011. After eliminating editorial and executive reports (8) and articles that appeared in more than one of the databases (16), there remained 110 articles on SCG. A further 33 were eliminated because the keywords only appeared in the references or in items mentioned in the text. Working papers and other items not subjected to peer-review process were excluded. Thus, the final sample consisted of 77 articles published in various journals, for example: Supply Chain Forum: An International Journal (6); 
Journal of Business Logistics; (4) and of particular note the International Journal of Operations \& Production Management (2) and the Journal of Operations Management (2).

Once these articles were identified, a concept-based approach (Webster \& Watson, 2002) was adopted in the third step. Two researchers from our group analyzed all the papers. A matrix was then created with the following information from each article: author names, year of publication, source name, purpose of the study, keywords, elements related to SCG and classification with respect to SCG (concepts, governance structure, governance mechanisms and others). Thus, two major themes related to SCG emerged: IT and supply chain performance.

In this survey, the elements found that addressed SCG were: capacity, transaction codification, transaction complexity, collaboration, commitment, trust, contracts, control, cooperation, coordination, transaction costs, flexibility, incentives, integration, opportunism, power, supplier qualification and relationship ties (Fawcett, Ogden, Magnan, \& Cooper, 2006; Gereffi, Humphrey, \& Sturgeon, 2005; Ruben, Boselie, \& Lu, 2007; Veen-Dirks \& Verdaasdonk 2009; Wathne \& Heide 2004; Zhang \& Aramyan, 2009).

Two studies were found that highlighted the importance of IT in SCG. Bitran, Gurumurthi and Sam (2006) argue that IT plays a key role as a driver of fundamental changes in supply chain behavior as well as changes in governance. Ghosh and Fedorowicz (2008) point out that IT is used for coordinating activities and sharing information among members of the supply chain, and depends on the existence of a cohesive set of communication processes to enable governance. Thus, it is necessary to analyze and study how IT is being used in the SCG activities and processes.

In addition, we identified other studies that highlight the importance of measuring and identifying supply chain performance. Whipple, Frankel, and Anselmi (1999) explored the trade-off between cost and performance in supply chains based on the selected SCG. Gyau and Spiller (2008) investigated the relationship between SCG types and perceived performance in relationships within a chain. Liu, Luo and Liu (2009) studied the different roles of chain governance in improving performance in emerging Asian economies.

Thus, the model being proposed herein is based on the interaction and measurement of supply chain governance constructs, investments in information technology and its impact on supply chain performance. The constructs and their underlying theories are presented below.

\section{Supply Chain Governance and IT}

Our survey of studies into SCG revealed several elements and aspects of governance. In many studies the elements were classified as either part of the governance structure or the governance mechanisms. However, some elements, such as trust, contracts and incentives were classified as being part of both the governance structure and the governance mechanisms. Thus, this classification was disregarded and the elements were grouped into concepts (contractual, relational and transactional) and related to information technologies, using the following governance theories (Cornforth, 2003; Rodrigues \& Malo, 2006): agency theory, stewardship theory, resource dependence theory and transaction cost theory.

\section{Agency theory - contractual governance and IT}

With the aid of agency theory it can be seen that the members within a supply chain relationship have different interests. The principal and the agent, two pillars of the theory (Jensen \& Meckling, 1976), sell and buy products from companies within the supply chain. Although they may play different roles in the relationship, generally the leader, or most important member of the chain, can be considered the principal, while the 1st, 2nd and 3rd level suppliers, for example, are the agents. 
Consequently, coordination and control among supply chain members is a governance function. The leading firm (principal) uses contracts to guarantee that its suppliers (agents) act according to its interest. Moreover, the leading firm often sets the rules and conditions that the others are expected to follow, thus indicating the power relations in the relationship. Incentives in the form of awards to the best performing suppliers may also be used to ensure the leading firm obtains the required inputs and services under the best possible conditions. Therefore, according to this theory, it is possible to analyze the elements of SCG: contract (Ferguson, Paulin, \& Bergeron, 2005), power relations (Gereffi et al, 2005), incentives (Veen-Dirks \& Verdaasdonk, 2009), coordination (Gereffi et al., 2005) and control (Veen-Dirks \& Verdaasdonk, 2009) which establish the existence of contractual governance.

There are several information systems for managing contracts (Bueren, Schierholz, Kolbe, \& Brenner, 2004) that can reduce costs while ensuring compliance and control regarding an agreement. The use of technologies may be influenced by incentive schemes, including rewards, training and education for users (Gunasekaran \& Ngai, 2004). Power is also considered as an element in a supply chain, where the technologies used allow the retention of some of the advantages and benefits of the existence of that power (Subramani, 2004). The use of IT has changed the patterns of coordination among firms in supply chains, by increasing the capacity to transfer information, providing incentives and controlling a number of activities required in the supply chain (Silva \& Fischmann, 1999). According to Gereffi, Humphrey, and Sturgeon (2005) the key issue in production on a global scale is that, through investments in different technologies, coordination and control can be achieved without the direct participation of individuals.

\section{Transaction cost theory - transactional governance and IT}

Transaction Costs Theory postulates that the firm is seen as a governance structure that serves as a mechanism to minimize transaction costs (Williamson, 1979). The adverse effects of bounded rationality and the protection of transactions against opportunistic attitudes can be minimized by using several different organizational forms (Cornforth, 2003). Thus, with regard to supply chains, the following elements of SCG were listed: transaction costs, transaction complexity, transaction coding and opportunism.

In light of this theory, we infer that companies try to avoid or minimize the existence of opportunism by using encrypted trading and minimize the costs of transactions with other companies. Regarding such transactions, the more complex they are, the more costly they are for firms. Thus, the elements found in the literature on SCG: cost (Ruben et al., 2007), complexity (Ashenbaum, Maltz, Ellram, \& Barratt, 2009), coding (Gereffi et al., 2005) and opportunism (Ruben et al., 2007) were analyzed and grouped using transaction cost theory, which compose transactional governance.

For Chong, Ooi and Sohal (2009) IT tools provide benefits in terms of efficiency by reducing transaction costs in relation to the external costs of internal coordination. Furthermore, technology can reduce transaction costs and communication between members of the chain. Another important element of IT use in a supply chain is the ability to reduce the incidence of opportunism among members because it increases the cost of opportunism due to the adoption of and investments in technologies (Park \& Yun, 2004). Some technologies create coding standards that must be negotiated and incorporated into a supply chain. Hence, depending on the supply chain and the products involved, more complex operations are identified and care is needed with the use of such IT.

\section{Stewardship and resource dependence theory - relational governance and IT}

One alternative to agency theory is stewardship theory (Barney, 1990) according to which the principal and the agents, or the leader firm and the suppliers, are seen as partners with harmonious and shared interests. According to this perspective, managers are not motivated by personal goals or the objectives of just one organization, but instead, they are aligned with the objectives of the partner organizations (Davis, Schoorman, \& Donaldson, 1997). 
Several studies identify collaboration (Fawcett et al., 2006), commitment (Fawcett et al., 2006), integration (Ashenbaum et al., 2009) and trust (Yu, Liao, \& Lin, 2006) as being key elements in SCG. They express how the members of the supply chain can achieve closer and more enduring relationships. These elements indicate the degree to which the firms participating in the supply chain share common goals and the possibility of them carrying out activities that are aligned with those objectives.

According to resource dependence theory, in order to survive, organizations rely heavily on their relationships with the external environment (Pfeffer \& Salancik, 1978). A coalition of organizations is formed, often with the goal of acquiring scarce resources in an uncertain environment (Ulrich \& Barney, 1984). Governance is a set of practices intended to obtain the required information and resources from the external environment to ensure the survival of an organization (Rodrigues \& Malo, 2006).

Therefore, relationship ties between firms constitute an important element in supply chain context (Zhang \& Aramyan, 2009). To survive and maintain their market competitiveness, organizations engage with each other in order to acquire the resources they desire and require. Furthermore, within the interaction among firms, some elements, such as the suppliers' capacities (Gereffi et al., 2005) to obtain and provide the required information and materials must be noted.

A supplier's qualification and flexibility to respond quickly and accurately to market changes contribute to the existence of relationships and a firm's survival (Wathne \& Heide, 2004). Organizations that rely on resources from the environment may become vulnerable (Humphreys, Lai, \& Sculli, 2001), showing the importance of this elements. Based on these latter two theories and their related elements identified in the literature on SCG, one can identify a 'relational governance'.

IT has a supporting role in the relationship between suppliers, buyers, producers and distributors, which can benefit all participants (Maçada, 2001). Integrated management processes, which are necessary to improve supply chain operations, require an increased level of communication between links in the chain. Thus, IT becomes important due to its ability to facilitate an increased volume of communication and to enhance the collaboration, reliability and commitment between chain members (Ghiassi \& Spera, 2003). Additionally, it can enable the integration of information, as well as physical and financial flows between firms and their supply chain partners (Rai, Patnayakuni, \& Seth, 2006). Pereira (2009) presents important aspects of IT use in supply chains to better manage information, make the supply chain more flexible and provide greater integration or interconnectivity between systems.

Gunasekaran and Ngai (2004) emphasize the long-term benefit for all parties in a supply chain that results from collaboration and information sharing, highlighting the importance of the application of IT. In addition, IT can help improve relationships with suppliers, ensuring the quality of their products or services by reducing fraud and error (Machado, Oliveira, \& Campos, 2004). Thus, quality should also be considered in evaluating the capabilities of suppliers and potential suppliers, where facilities, equipment and employees are taken into consideration (Correia, 2002).

\section{Supply Chain Performance}

The supply chain has become a very important area of company management in the 21 st century and has considerable influence on business performance (Gunasekaran \& Ngai, 2012). For Aramyan, Ondersteijn, Kooten, and Lansink (2006) there are a number of performance indicators, but there is a lack of consensus regarding what determines performance in such chains. The debate is made broader due to the fact that performance can be defined and assessed in several ways, but some definitions and indicators are widely accepted (Claro, 2004). 
In their research, Li, Ragu-Nathan, Ragu-Nathan and Rao (2006) confirm the existence of a positive relationship between supply chain practices and performance. For these authors, the practices are the set of activities undertaken by an organization to promote effective management of their supply chain. The practices identified in their study were: strategic partnership with suppliers and customer relations.

For Betts and Tadisina (2009), chain performance can be measured using operational metrics such as volume flexibility, scheduling flexibility, quality and costs, as well as financial metrics such as return on investment, profit as a percentage of sales and the current value of the firms. Furthermore, Flynn, Huo and Zhao (2010) highlight increased sales, increased profits, increased market share and increased return on investments as financial measures of organizational performance.

For Zhang and Aramyan (2009) there is a relationship between the type of governance and supply chain performance that can be measured by efficiency, flexibility and responsiveness. Efficiency measures how resources are used by applying measures such as production costs, profitability, return on investment and stock. Flexibility indicates the level of a chain's response to market changes and customer requests, including customer satisfaction, volume flexibility, delivery, and reduction of the number of lost sales. Responsiveness is related to product orders: order time, customer complaints, shipping errors and customer response time.

\section{A Proposed Model}

The review of SCG studies revealed a number of elements that were grouped using the different theories. The contract, power, incentives, coordination and control relating to contractual governance elements were grouped based on agency theory. Relational governance, supported by the theories of stewardship and resource dependence, encompasses the relationship ties, flexibility, qualification, capacities, trust, integration, commitment, collaboration and cooperation elements. Finally, transactional governance, supported by transaction costs theory, is related to the cost, complexity, coding and opportunism elements.

SCG and its concepts, according to the studies presented here, are influenced by investments in different technologies. IT investments have a supporting role in relationships and provide long-term benefits by facilitating cooperation, collaboration and information sharing. Moreover, such investments enable a reduction in transaction costs, by reducing the complexity of such transactions and creating patterns of information exchange. They promote a reduction in opportunism because of the increased transparency in trade. There are different systems for managing contracts, thus facilitating their elaboration and control. IT investments also enable greater control and coordination of chain activities, the tracking of products and processes, and can serve as incentives for firms to invest more in IT. The exercise of power can also be facilitated by the use of technologies and investments in the chain.

As mentioned above, SCG influences chain performance, and, according to Zhang and Aramyan (2009), there is a relationship between the type of governance and performance, in which the financial and operational aspects can be highlighted. The former are related to increases in sales, profit on sales and return on investment (Flynn, Huo, \& Zhao, 2010). The operational aspects, according to Betts and Tadisina (2009), can be measured by volume flexibility, product quality and overall costs in the chain. Figure 1 shows a proposed model with five constructs and 24 elements which can be supplemented and revised with data obtained from the qualitative and quantitative stages presented in the following sections. 


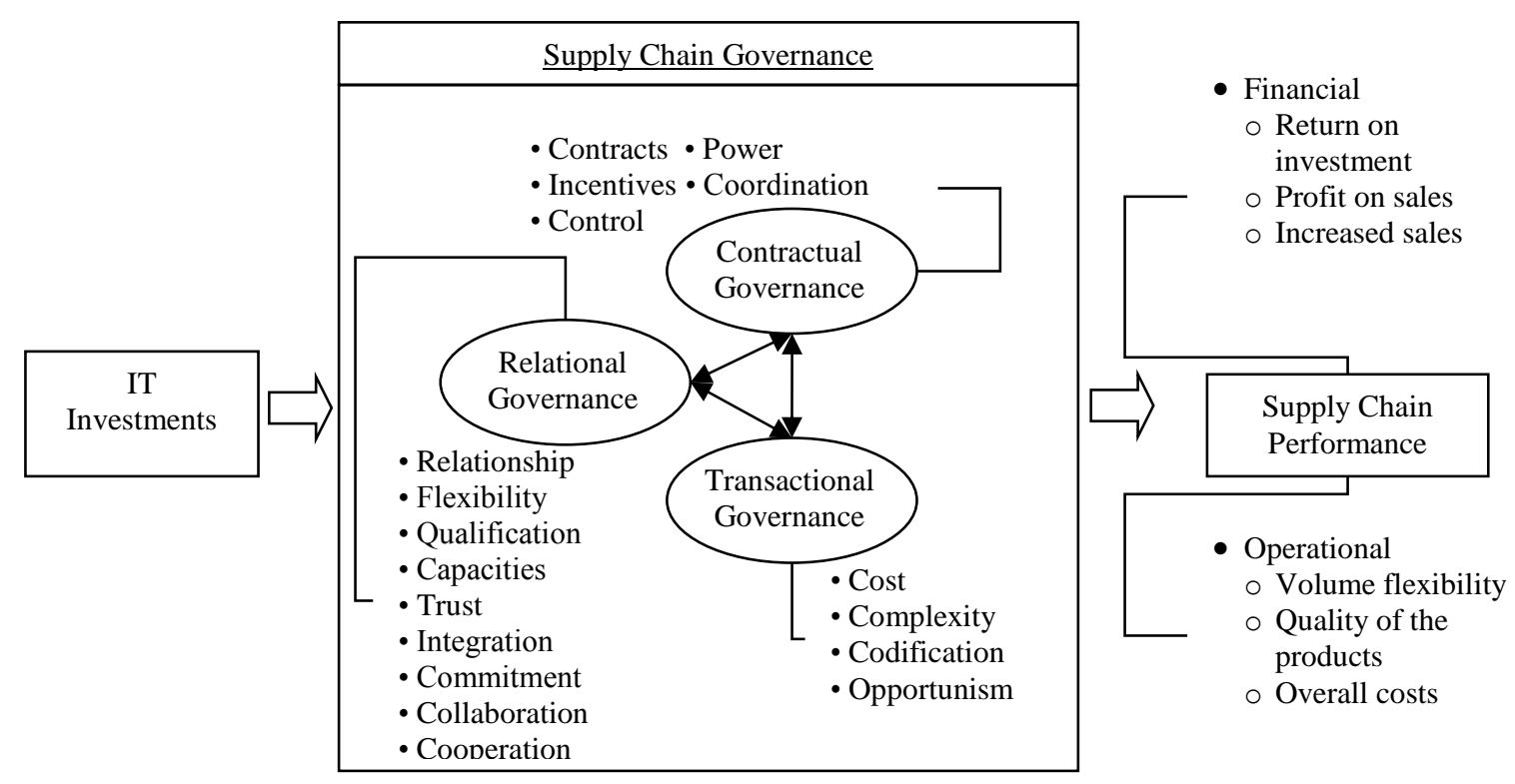

Figure 1. Proposed Model.

Source: Elaborated by the authors.

\section{Method}

This research is a pilot study with two stages, one qualitative and another quantitative. In the qualitative stage, the research strategy consisted of carrying out two case studies in six firms. A qualitative study is appropriate for this research because it seeks to describe the complexity of a given situation, to understand the dynamic processes and analyze the interaction of the variables (Yin, 2009) related to SCG, IT and supply chain performance.

The research was conducted in two large companies in important sectors of the Brazilian economy (automotive and electronics), and two important suppliers for each of the companies. These organizations are among the largest in the country and are part of the 200 largest business groups in the world (Exame, 2012; Forbes, 2013). Their suppliers provide $70-100 \%$ of certain products and these big companies account for $20-40 \%$ of suppliers' revenues.

The sources of evidence in the research included interviews with executives, corporate websites and documents provided by the companies. The interviews were conducted between November 2010 and May 2011 with the top executives responsible for each of the large companies' supply chain. The individuals involved have considerable experience and have worked in the supply chain area for many years, and also have knowledge regarding IT investments and their use in chains. Documents referring to the strategic planning of the companies' supply chains, corporate presentations (presented during interviews) and information from the corporate sites (firm characteristics, market share, product traded, awards and business highlights) were used.

In Case 1, interviews were held with the Vice President of Supply Chain for the Americas of the large company and key executives related to the supply chain area of its suppliers: (a) plant manager and logistics manager and (b) logistics manager, quality systems auditor, relations manager and project manager. In Case 2 interviews were held with the Supply Chain Manager of the large company and key executives (Director of Sales) of the suppliers who had knowledge of the logistics processes and the technologies used. The interviews, which were recorded and transcribed, lasted 1 hour and 30 minutes on average. When selecting the interviewees, some characteristics were taken into account, such as the length of time they had worked in the supply chain, length of time in this area in the 
present company and knowledge of the subject under study. Another feature of this research is that the companies involved have large structured chains with hundreds of products and suppliers.

The content analysis procedure, which consists in discovering the fundamental meanings of the communication, whose presence or frequency of appearance may be significant for the purpose of the chosen analysis (Bardin, 1977), was adopted in the analysis of the responses. Categories were determined based on clusters of meanings (units), which were separated into three categories: final (concepts - contractual, relational and transactional, SCG, IT investments and supply chain performance), intermediate (SCG elements, IT investment features, IT and SCG elements, definition of chain performance, other performance measures) and initial (definitions, characteristics, uses and examples).

The quantitative stage consisted of a pre-test designed to help refine the model. The pre-test, according to Malhotra (2006), is intended to test the preliminary research instrument on a small sample of respondents in order to identify and eliminate any potential problems, thus permitting its improvement and refinement. This type of data collection procedure also permits the removal of items and dimensions that are unnecessary or inappropriate in the desired measurement (Fowler, 1993). In this stage, we adopted a model refinement process adapted from Koufteros (1999): (a) Development of the instrument, from a theoretical basis, definitions of variables and face and content validity; (b) Data Collection; (c) Reliability Analysis - Cronbach's alpha and Corrected Item-Total Correlation (CITC) of the constructs and instrument; and (d) Exploratory Factor Analysis on the block with a test for unidimensionality.

The survey instrument was divided into three main parts: IT investments, supply chain governance and supply chain performance. The items in the construct IT investments were presented in the form of statements, such as: "Our company invests in IT to track applications and products", to which the respondents were asked to identify the degree to which they agreed. Similarly, in the construct supply chain governance the respondent was asked to identify the extent to which the company agrees with statements related to the construct, for example, "Our company controls the activities and processes of suppliers and buyers". In these two constructs the indicators were operationalized on a 7-point Likert scale ranging from strongly disagree (1) to strongly agree (7). In the third construct, supply chain performance, the respondents were asked to evaluate their company's performance in relation to their largest and main competitors on a scale ranging from much worse (1) to much better (7).

\section{Qualitative Stage}

In Case 1, seven executives were interviewed from the three above-mentioned companies from the automotive sector. Based on content analysis of the interview transcripts 272 initial categories were found (e.g., Qualification of the supplier is to analyze all the aspects, Flexibility is to react to the plans, Company A does not have integrated systems, Company B controls deliveries) 47 intermediate categories (e.g., Transaction costs, Supplier capacity, Coordination, IT investments, IT Investment and Contractual SCG, Integration) and five final categories (IT Investment and SCG, Contractual Governance, Relational Governance, Transactional Governance, SCG and supply chain performance). In Case 2, an executive was interviewed from each company in the electronics sector. Content analysis of the interview transcripts led to the identification of 252 initial categories (e.g., communication between Companies B and C for collaboration, IT to minimize costs, Flexibility to correct errors, Cooperation is the same as collaboration), 44 intermediate categories (e.g., control, IT Investment and relational SCG, relationship ties, Definition of chain performance) and five final categories (IT Investment and SCG, Contractual Governance, Relational Governance, Transactional Governance, SCG and supply chain performance). 
Regarding SCG, virtually all the elements and concepts were confirmed by the respondents. The element cooperation in relational governance was not validated by all the respondents. Only a small semantic difference was identified between the two elements: collaboration and cooperation. Several studies were found concerning cooperation as part of chain governance (A. Ross \& Goulding, 2007; Henderson \& Cool, 2010). However, there is no consensus, nor a definition of the element. Thus, cooperation was not identified as a separate element in Relational SCG, but instead as being very close to collaboration between the companies.

The element opportunism in the transactional concept, was often confused with opportunity and was identified as something negative and pejorative by the respondents, who suggested the term might affect the response of the respondents, which could change the understanding of this aspect. So, the respondents suggested replacing the element opportunism with 'transparency in transactions between companies in the chain'. This finding is supported in the literature, because according to Lamming, Caldwell, Harrison and Phillips (2001), transparency in supply chain relations can minimize the effects of opportunism and favor a more positive perception in the chain.

In addition, an element emerged in the concept contractual governance (informal contracts) that was not present in the original model. In the literature, references were found to the existence of informal contracts or informal safeguards (Ferguson et al., 2005) in supply chain activities. This element was not specified in the original model because it encompassed all types of contracts, but it came to be considered an important aspect. Thus, we decided to separate the two types of contracts highlighted in the qualitative stage. In the cases, these informal contracts were found to exist in some situations where companies have an enduring history and the inclusion of formal contracts is no longer necessary, nor well regarded. We decided to insert this element in the model in relation to SCG.

In the construct IT investments related to SCG, the content analysis revealed a number of elements related to each of the SCG concepts: monitoring, tracking, information sharing, integration and cost reduction. The monitoring of logistics indicators such as price, quantity and quality was found to be related to SCG. Products and order tracking can also be achieved through investments in technology by companies in the chain. Information sharing, frequently cited by the interviewees, is a crucial element when addressing the relationship between IT investments in SCG. The integration of activities in the supply chain is an important element highlighted by the companies as a relevant aspect when analyzing SCG. Lastly, investments in IT can streamline trade between a company and its business partners, which allows the company to reduce costs in such activities in a chain. Thus, five elements emerged that can be used to identify and measure the influence of IT investments in SCG. These elements emerged from the analysis and were not in the original model, so the model was enhanced and enlarged with respect to the influence of IT investments on SCG.

The elements of the supply chain performance were all confirmed by the interviewees. It was suggested, however, that the scope of the the overall costs element be widened with the inclusion of elements related to the costs of transportation, production, inventory and delivery. In addition, marketrelated elements emerged from the content analysis, they are: market share, customer satisfaction and return on sales. Thus, these market-related elements were added to the original model with respect to supply chain performance. Thus, with the completion of the qualitative stage, the model had 5 constructs and 32 elements: IT investments (5), contractual governance (6), transactional governance (4), relational governance (8) and chain performance (9).

\section{Quantitative Stage}

Following the steps of the model refinement process adapted from Koufteros (1999), a survey instrument was developed based on the literature review and the analysis and results from the qualitative stage. The questions in the survey instrument were elaborated from the constructs and items in Figure 1. 
To achieve face and content validity, the instrument was first validated by academics and practitioners with experience in the IT and supply chain areas. At this stage the constructs and items were presented and discussed to check the comprehension of the preliminary questionnaire, and to verify the clarity and organization of the questions. All the interviews in this stage were conducted in the presence of one of the researchers. Thus, content validity was conducted to verify the comprehension and the problems involved in answering the questions, and face validity was conducted to verify the adequacy of the form and vocabulary, so as to approximate it to that of the future respondents.

Next, data were collected from 38 executives from large companies, 15 of whom were graduate students of production engineering. The graduate students were professionals related to the areas of logistics, procurement and business operations in their respective companies. The questionnaires were distributed to the students in the intervals between classes, while an email was sent to the other managers from large companies explaining the purpose of the study with the questionnaire attached in electronic form. Data were collected in September 2012. Respondents from smaller companies and respondents from areas other than logistics, procurement or business operations were identified. Thus, 5 questionnaires were excluded, leaving 33. Afterwards, the database was purified, during which an analysis was made of the outliers to identify respondents whose answers showed a standard deviation greater than 2, who answered using only two items on the scale, or who did not answer all the issues, eliminating 3 more questionnaires, leaving 30 completed questionnaires, which constituted the research sample used for refinement of the proposed model.

The companies analyzed were from the following business sectors: consumer goods (40\%), automotive (20\%), food processing (17\%), transport and distribution (13\%) and retail (10\%). Of these, 47\% have revenues of more than 100 million Brazilian reais and 54\% employ more than 500 people. The respondents were mostly directors or managers $(66 \%)$, analysts $(20 \%)$ or supervisors $(10 \%)$, while the executives who responded to the survey hold mainly middle or senior positions. In addition, on average the respondents had eight years of experience working in the supply chain area and five years, on average, in their current position.

In the third step, according to Koufteros (1999), reliability analysis was performed, using Cronbach's Alpha and Corrected Item-Total Correlation (CITC) of the constructs and instrument as parameters. Then, in this stage the reliability of the instrument and its constructs were tested using Cronbach's alpha coefficient, which is capable of measuring internal consistency. According to Hair, Anderson, Tatham and Black (2005), 0.70 is usually the lowest acceptable value, but it may be as low as 0.60 in exploratory research (Hair, Anderson, Tatham, \& Black, 2005). Thus, Table 1 shows the results obtained for the model before the adjustments and for the final model, calculated after the refinement process, starting with the elimination of the outliers, determination of the CITC presented below and the factor analysis.

Table 1

\section{Reliability Indices of the Constructs}

\begin{tabular}{lccc}
\hline Proposed Constructs & $\begin{array}{c}\text { Chronbach's Alpha before } \\
\text { Adjustments }\end{array}$ & $\begin{array}{c}\text { Chronbach's Alpha after } \\
\text { CITC }\end{array}$ & $\begin{array}{c}\text { Chronbach's Alpha } \\
\text { Final Model }\end{array}$ \\
\hline IT Investments & 0.871 & 0.87 & 0.87 \\
Contractual SCG & 0.428 & 0.740 & 0.740 \\
Relational SCG & 0.851 & 0.884 & 0.884 \\
Transactional SCG & 0.540 & 0.60 & 0.60 \\
Chain Performance & 0.804 & 0.805 & 0.814 \\
Instrument & 0.906 & 0.93 & 0.93 \\
\hline
\end{tabular}


The next step was to analyze the corrected item-total correlation which measures the correlation between the items of the same factor, thereby determining to what degree the items share the same meaning (Churchill, 1979). For Hair et al. (2005), items with a CITC lower than 0.5 should be eliminated from the survey instrument. However, Simsion (2007) suggests the elimination of items with CITC indices of less than 0.3, which was adopted in this research.

Thus, the items with CITC below the stipulated value (0.3), and that caused a reduction in the value of the Cronbach's alpha, were eliminated - a total of three items, namely: informal contracts with suppliers and buyers, Flexibility in relation to suppliers and buyers and profit. Table 2 shows the variation in the CITC values found by construct in the model before adjustment and the final model. We can identify an improvement in CITC final model compared with before adjustment. After we carry out an elimination of the three elements mentioned (informal contracts, Flexibility and profit) we can observe an improvement both in CITC final model and Cronbach's alpha.

Table 2

\section{Corrected Item-Total Correlation of the Constructs}

\begin{tabular}{lll}
\hline Proposed Constructs & CITC Model before Adjustments & CITC Final Model \\
\hline IT Investments & $0.424-0.699$ & $0.463-0.705$ \\
Contractual SCG & $-0.251-0.640$ & $0.334-0.634$ \\
Relational SCG & $0.179-0.783$ & $0.577-0.821$ \\
Transactional SCG & $0.354-0.536$ & $0.353-0.588$ \\
Chain Performance & $0.164-0.658$ & $0.362-0.764$ \\
\hline
\end{tabular}

After the reliability analysis, the Cronbach's alpha coefficients of the constructs in the instrument consisting of five constructs and 29 elements (obtained after the analysis of reliability) are between 0.60 and 0.88 while the instrument coefficient is 0.93 (Table 1), demonstrating an improvement in reliability. We also found that by eliminating the items with CITC values below 0.3 , using Simsion (2007) as reference, the CITC values of all the constructs improved.

Finally, Convergent Exploratory Factor Analysis was performed to verify that the proposed constructs were truly unidimensional, that is, whether the respondents understand that all the items composing the construct refer to the same subject. The method chosen to determine the factors was Component Analysis, because it uses the total variance of the items, together with the Varimax orthogonal rotation method. Table 3 presents the intra-block factor loadings of the constructs, the eigenvalues and percentage of variance explained.

Table 3

Intra-Block Factor Analysis of the Constructs

\begin{tabular}{lccc}
\hline Proposed Constructs & Factor loads & Eigenvalues & \% Explained Variance \\
\hline IT Investments & $0.620-0.923$ & 3.321 & 66.14 \\
Contractual SCG & $0.620-0.872$ & 2.338 & 58.46 \\
Relational SCG & $0.628-0.902$ & 4.25 & 60.71 \\
Transactional SCG & $0.532-0.822$ & 1.77 & 44.20 \\
Chain Performance & $0.619-0.838$ & 3.21 & 53.55 \\
\hline
\end{tabular}

The constructs IT investments, relational SCG and transactional SCG were found to be unidimensional. However, this was not the case with the construct contractual SCG. In this construct 
the item power relations had a load slightly below the required 0.5 (Hair et al., 2005) and was removed from the model. This infers that power was not considered a separate element of contractual governance, since it is exercised through contracts, control, while coordination in the supply chain can be enhanced through the use of financial incentives and through recognition of the suppliers. According to Gereffi et al. (2005) and Ghosh and Fedorowicz (2008), power may be exercised in the chain through the control of processes and resources that the other companies need, with explicit coordination of such processes.

The construct chain performance was found not to be unidimensional, and the items product quality and customer satisfaction were eliminated from the instrument. This suggests that the quality of products is more closely related to the operational aspects within the chain and is not related to the concept of governance, while profit was seen as being part of the return on investment and return on sales.

So after the refinement process, the constructs in the present model presented a capacity to explain variance of between $44.2 \%$ and $66.14 \%$, indicating that these constructs can explain what is being analyzed. Following this step, reliability was again calculated and coefficients of between 0.60 and 0.88 were found (Table 1$)$, demonstrating the reliability of the instrument $(0.93)$, with 5 constructs and 26 items or elements.

\section{Discussion of Proposed Model}

The bibliographical survey led to the development of a proposed a model with five constructs and 24 elements. Due to the scarcity of studies into the influence of IT investments on supply chain governance, the construct IT investment was only explored in the later stages of the exploration and refinement of the model. Thus, following the qualitative stage of the study, it was possible to propose a model with 32 elements related to the five constructs.

During this stage, there were some changes to the model, mainly in IT investments related to SCG. The products and order tracking can be reached through IT investments by companies in their supply chains, showing a relationship with contractual SCG. For example, investments in warehouse management system (WMS), enterprise resource planning (ERP), e-procurement, electronic data interchange (EDI), barcode, radio-frequency identification (RFID) and tracking systems could help companies achieve the monitoring and tracking of products and orders. Information sharing and integration are crucial and relevant aspects when analyzing relational SCG. We can infer that managers invest in technologies, such as EDI, Vendor Managed Inventory (VMI), ERP and eprocurement for a closer and lasting relationship with suppliers and buyers.

And lastly, IT investments can speed up commercial trades between a company and its business partners, enabling reductions in company costs in such supply chain actions. Investments in WMS, ERP, e-procurement, EDI, barcode, RFID and tracking system could help companies reduce costs in supply chain transactions, showing a relationship between IT and transactional SCG. So, five elements were isolated that can be utilized to identify and measure the influence of IT investments on SCG: monitoring, products and orders tracking, information sharing, integration and cost reduction.

We made other changes to the model, such as the inclusion of an element (informal contracts) in the construct contractual governance. The case studies showed that informal contracts were widely cited, which led the authors to distinguish between formal and informal contracts. This finding is consistent with Jain and Dubey's (2005) findings, which highlighted the existence of informal contracts based on trust and long-term relationships between enterprises. Another modification was the inclusion of the element transparency in the construct transactional governance. In the cases, transparency emerged as a counterpoint to opportunism, which was perceived as having negative connotations, being associated with the goal of taking advantage of situations. 
In addition, new elements emerged in the construct supply chain performance with respect to the market in which the companies operate. In the case studies, the market was seen as an important variable for measuring chain performance with respect to market share (Iyer, Germain, \& Claycomb, 2009), customer satisfaction (Hsu, Kannan, Tan, \& Leong, 2008) and increased sales (Iyer et al., 2009). These three variables were more frequently seen in the case of the automotive sector, where they were making efforts to increase market share by increasing sales and customer satisfaction, which affected their performance in the chain.

Another modification to the model was the elimination of the element cooperation from the construct relational governance, because it was considered very similar to the element collaboration. Several studies were identified that dealt with cooperation as an element of SCG (A. Ross \& Goulding, 2007; Henderson \& Cool, 2010). However, there is no consensus, nor even a definition of the element. Thus, the results of this study suggest there is no difference between cooperation and collaboration with respect to relationships in supply chains.

Finally, in the quantitative stage of the study, with the aid of a model refinement process adapted from Koufteros (1999), 5 constructs and 26 elements were found, as can be observed in Figure 2.

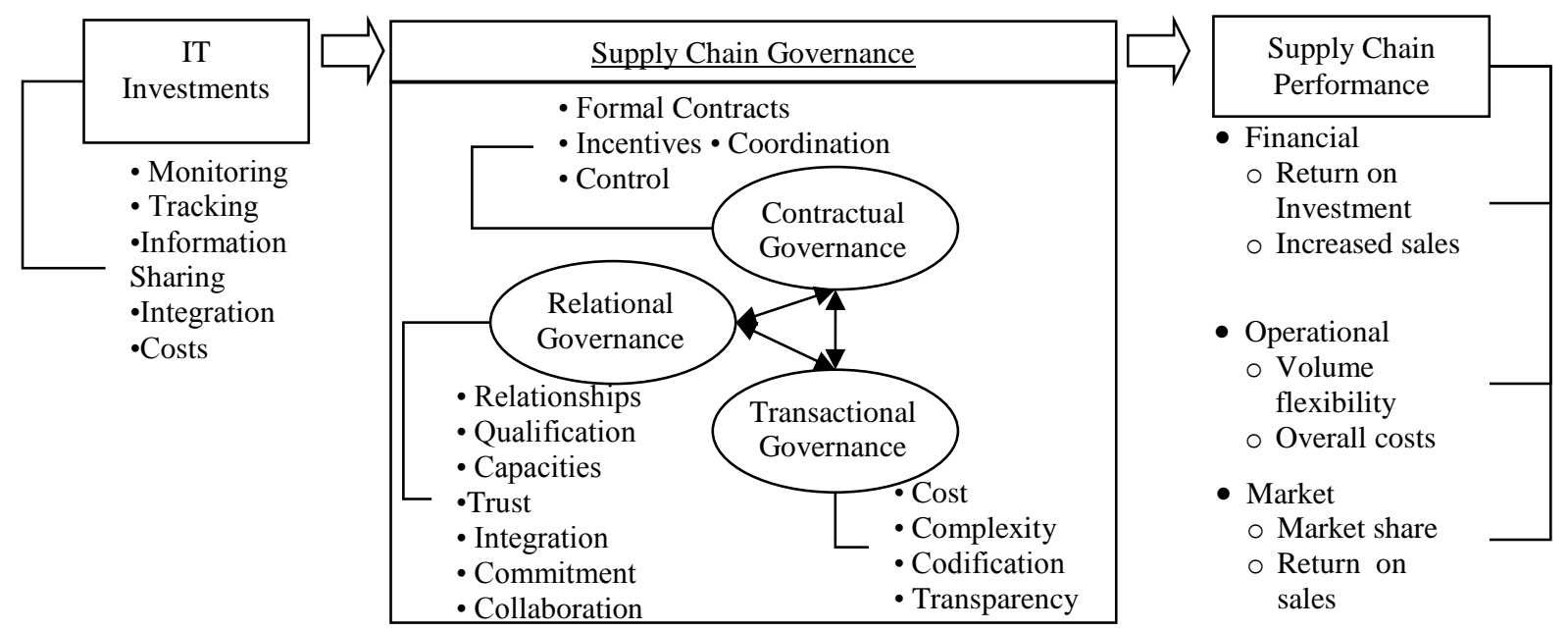

Figure2. Final Model.

Source: Elaborated by the authors.

We eliminated the element informal contracts from the model because the executives did not view this type of contract as being important in chain relationships. Moreover, the element transparency, which had been added during the qualitative stage, was retained in the final model, while opportunism was eliminated. Opportunism was understood to represent a negative reference for the respondents while transparency positively captures the relationship between the companies, regarding whether or not to take advantage of a situation, as pointed out by Lamming et al. (2001).

After the quantitative step we didn't make modifications in either the IT investment construct or in supply chain performance. Thus, Figure 2 represents the final model of this study regarding IT investments, supply chain governance and supply chain performance. 


\section{Final Remarks}

The objective of this pilot study, to propose a model linking IT investments, supply chain governance and supply chain performance, was achieved using a two-stage approach, one qualitative and another quantitative.

Based on the bibliographical survey, SCG has received considerable attention in the literature (Jain \& Dubey, 2005; Zhang \& Aramyan, 2009), with IT being one of the main drivers, although few studies have explored this topics together (Bitran et al., 2006; Ghosh \& Fedorowicz, 2008). Thus, the five constructs (Figure 1), with their elements and items were proposed and refined, based on consolidated references from the literature.

After qualitative and quantitative steps, we proposed a model with 5 constructs and 26 elements (Figure 2) combining IT investment, SCG and supply chain performance. Despite being part of a pilot study, the model provides both academic and practical contributions.

Regarding the academic contribution, several theories were used to analyze the elements of SCG, advancing the discussion proposed by Terpend, Tyler Krause and Handfield (2008), who suggested the need to use multiple theories to explain the relationship between firms in supply chains. Moreover, according to Chen and Paulraj (2004) many elements are critical to achieve success in a supply chain, with IT being one of the most important. Thus, IT plays a key role in the model, since it encompasses and increases the understanding of these processes and activities related to SCG. Viewing SCG in terms of different concepts (contractual, relational and transactional) helps managers to analyze various aspects of the supply chain in which they participate and to make better decisions that benefit the company(ies) in the supply chain.

Another contribution is related to the supply chain performance, since according to Aramyan et al. (2006) there are a number of performance indicators that can be used in chains, but there is a lack of consensus regarding what determines supply chain performance. In the present study, based on the literature review and the qualitative and quantitative stages, we determined that chain performance can be measured using financial, operational and market measures. The practical contributions are that the model can be considered a representation of reality since it involves many elements that were perceived in practice by the companies, found in the literature and mentioned by experienced executives from the large, globally-relevant Brazilian companies who were interviewed in this study. Thus, due to the identification of the different SCG elements and how IT can assist in these processes and activities, hence influencing chain performance, managers can make better decisions based on the analysis of multiple variables.

Finally, one of the study's limitations was the impossibility to generalize the results obtained due to a non-probabilistic sample approach. The analyzed companies are in different sectors and have a great importance for Brazil, but these results cannot be used to represent companies across the country due to the non-probabilistic nature and not including all states and other relevant sectors, in both the qualitative and quantitative steps. Thus, the survey results contribute to a better understanding of the phenomenon, but cannot be generalized.

Another limitation is the cross-sectional nature of the study. This approach is based on analysis of data collected at a single point in time and may be influenced by external variables. Thus, the proposed model in this study reflects the perceptions of executives from the supply chain and logistics only at the time of this study. 


\section{References}

Aramyan, L. H., Ondersteijn, C., Kooten, O., \& Lansink, A. O. (2006). Performance indicators in agrifood production chains. In C. J. Ondersteijn, J. H. Wijnands, R. B. Huirne, \& O. Kooten (Eds.), Quantifying the agri-food supply chain (pp. 47-64). Dordrecht: Springer.

Ashenbaum, B., Maltz, A., Ellram, L., \& Barratt, M. A. (2009). Organizational alignment and supply chain governance structure: introduction and construct validation. The International Journal of Logistics Management, 20(2), 169-186. doi: 10.1108/09574090910981279

Bardin, L. (1977). Análise de conteúdo. Lisboa: Edições 70.

Barney, J. B. (1990). The debate between traditional management theory and organizational economics: substantive differences or intergroup conflict? Academy of Management Review, 15(3), 382-393. doi: 10.5465/AMR.1990.4308815

Betts, T., \& Tadisina, S. K. (2009, May). Supply chain agility, collaboration, and performance: how do they relate? Proceedings of Annual Conference of the Production and Operations Management Society, Orlando, USA, 20.

Bitran, G. R., Gurumurthi, S., \& Sam, S. L. (2006). Emerging trends in SCG [Working report 2006]. MIT Sloan School of Management, Cambridge, MA.

Bueren, A., Schierholz, R., Kolbe, L., \& Brenner, W. (2004, January). Customer knowledge management - improving performance of customer relationship management with knowledge management. Proceedings of the Hawaii International Conference on System Sciences, Hawaii, USA, 28.

Chen, I. J., \& Paulraj, A. (2004). Towards a theory of supply chain management: the constructs and measurements. Journal of Operations Management, 22(2), 119-150. doi: 10.1016/j.jom.2003.12.007

Chong, A. Y.-L., Ooi, K.-B., \& Sohal, A. (2009). The relationship between supply chain factors and adoption of e-collaboration tools: an empirical examination. International Journal of Production Economics, 122(1), 150-160. doi: 10.1016/j.ijpe.2009.05.012

Churchill, G. A., Jr. (1979). A paradigm for developing better measures of marketing constructs. Journal of Marketing Research, 16(1), 64-73. doi: 10.2307/3150876

Claro, D. P. (2004). Managing business networks and buyers-suppliers relationship (Doctoral dissertation). Wageningen University, Wageningen, Netherlands.

Cornforth, C. J. (2003). The governance of public and nonprofit organizations: what do boards do? London: Routledge.

Correia, G. M. (2002, October). A utilização do conceito de custos de transação na seleção de fornecedores de insumos produtivos na indústria farmacêutica. Anais do Encontro Nacional de Engenharia de Produção, Curitiba, PR, Brasil, 22.

Davis, J. H., Schoorman, F. D., \& Donaldson, L. (1997). Toward a stewardship theory of management. Academy of Management Review, 22(1), 20-47.

Exame.com. (2012). Maiores empresas do Brasil em 2012. São Paulo, SP: Editora Abril. Retrieved from http://exame.abril.com.br/negocios/melhores-e-maiores/ 
Fawcett, S. E., Ogden, J. A., Magnan, G. M., \& Cooper, M. B. (2006). Organizational commitment and governance for supply chain success. International Journal of Physical Distribution \& Logistics Management, 36(1), 22-35. doi: 10.1108/09600030610642913

Ferguson, R. J., Paulin, M., \& Bergeron, J. (2005). Contractual governance, relational governance, and the performance of interfirm service exchanges: the influence of boundary-spanner closeness. Journal of the Academy of Marketing Science, 33(2), 217-234. doi: 10.1177/0092070304270729

Flynn, B. B., Huo, B., \& Zhao, X. (2010). The impact of supply chain integration on performance: a contingency and configuration approach. Journal of Operations Management, 28(1), 58-71. doi: 10.1016/j.jom.2009.06.001

Forbes. (2013, May). The world's biggest public companies. Retrieved from http://www.forbes.com/global2000/list

Fowler, F. J. (1993). Survey research methods. Newbury Park, CA: Ed. Sage.

Gereffi, G., Humphrey, J., \& Sturgeon, T. (2005). The governance of global value chains. Review of International Political Economy, 12(1), 78-104. doi: 10.1080/09692290500049805

Ghiassi, M., \& Spera, C. (2003). Defining the internet-based supply chain system for mass customized markets. Computers \& Industrial Engineering, 45(1), 17-41. doi: 10.1016/S03608352(03)00017-2

Ghosh, A., \& Fedorowicz, J. (2008). The role of trust in supply chain governance. Business Process Management Journal, 14(4), 453-470. doi: 10.1108/14637150810888019

Gunasekaran, A., \& Ngai, E. W. T. (2004). Information systems in supply chain integration and management. European Journal of Operational Research, 159(2), 269-295.

Gunasekaran, A., \& Ngai, E. W. T. (2012). Decision support systems for logistics and supply chain management. Decision Support Systems, 52(4), 777-778. doi: 10.1016/j.dss.2011.11.012

Gyau, A., \& Spiller, A. (2008). The impact of supply chain governance structures on the inter-firm relationship performance in agribusiness. Agricultural Economics, 54(4), 176-185.

Hair, J. F., Jr., Anderson, R. E., Tatham, R. L., \& Black, W. C. (2005). Análise multivariada de dados. Nova Iorque: Bookman.

Henderson, E. J., \& Cool, K. O. (2010). Experience and learning in wine supply chain negotiations. Supply Chain Forum an International Journal, 11(1), 42-55.

Hsu, C.-C., Kannan, V. R., Tan, K.-C., \& Leong, G. K. (2008). Information sharing, buyer-supplier relationships, and firm performance: a multi-region analysis. International Journal of Physical Distribution \& Logistics Management, 38(4), 296-310. doi: 10.1108/09600030810875391

Humphreys, P. K., Lai, M. K., \& Sculli, D. (2001). An inter-organizational information system for supply chain management. International Journal of Production Economics, 70(3), 245-255. doi: 10.1016/S0925-5273(00)00070-0

Iyer, K. N. S., Germain, R., \& Claycomb, C. (2009). B2B e-commerce supply chain integration and performance: a contingency fit perspective on the role of environment. Information \& Management, 46(6), 313-322. doi: 10.1016/j.im.2009.06.002

Jain, K., \& Dubey, A. (2005). Supply chain collaboration: a governance perspective. Supply Chain Forum: An International Journal in Supply Chain, 6(2), 50-57. 
Jensen, M. C., \& Meckling, W. H. (1976). Theory of the firm: managerial behavior, agency costs and ownership structure. Journal of Financial Economics, 3(4), 305-360. doi: 10.1016/0304$405 X(76) 90026-X$

Ketchen, D. J., Jr., \& Hult, G. T. M. (2007). Bridging organization theory and supply chain management: the case of best value supply chains. Journal of Operations Management, 25(2), 573-580. doi: 10.1016/j.jom.2006.05.010

Koufteros, X. (1999). Testing a model of pull production: a paradigm for manufacturing research structural equation modeling. Journal of Operations Management, 17(4), 467-488. doi: 10.1016/S0272-6963(99)00002-9

Lamming, R. C., Caldwell, N. D., Harrison, D. A., \& Phillips, W. (2001). Transparency in supply relationships: concept and practice. Journal of Supply Chain Management, 37(3), 4-10. doi: 10.1111/j.1745-493X.2001.tb00107.x

Li, S., Ragu-Nathan, B., Ragu-Nathan, T. S., \& Rao, S. S. (2006). The impact of supply chain management practices on competitive advantage and organizational performance. Omega, 34(2), 107-124. doi: 10.1016/j.omega.2004.08.002

Liu, Y., Luo, Y., \& Liu, T. (2009). Governing buyer-supplier relationships through transactional and relational mechanisms: evidence from China. Journal of Operations Management, 27(4), 294309. doi: 10.1016/j.jom.2008.09.004

Maçada, A. C. G. (2001). Impacto dos investimentos em tecnologia da informação nas variáveis estratégicas e na eficiência dos bancos brasileiros (Tese de doutorado). Universidade Federal do Rio Grande do Sul, Porto Alegre, RS, Brasil.

Machado, A. G. C., Oliveira, M. V. S. S., \& Campos, J. R. R., Filho (2004, novembro). Teoria dos custos de transação: um estudo multi-casos de empresas integradas verticalmente. Anais do Simpósio de Engenharia de Produção, Bauru, SP, Brasil, 11.

Malhotra, N. (2006). Pesquisa de marketing: uma orientação aplicada (4a ed.). Porto Alegre: Bookman.

Melville, N., Kraemer, K., \& Gurbaxani, V. (2004). Review: information technology and organizational performance: an integrative model of it business value. MIS Quarterly, 28(2), 283-322.

Park, S.-Y, \& Yun, G. W. (2004). The impact of internet-based communication systems on supply chain management: an application of transaction cost analysis. Journal of Computer-Mediated Communication, 10(1), 00. Retrieved from http://onlinelibrary.wiley.com/doi/10.1111/j.10836101.2004.tb00237.x/full. doi: 10.1111/j.1083-6101.2004.tb00237.x

Pereira, J. V. (2009). The new supply chain's frontier: information management. International Journal of Information Management, 29(5), 372-379. doi: 10.1016/j.ijinfomgt.2009.02.001

Pfeffer, J., \& Salancik, G. (1978). The external control of organizations: a resource dependence perspective. New York: Harper \& Row.

Rai, A., Patnayakuni, R., \& Seth, N. (2006). Firm performance impacts of digitally enabled supply chain integration capabilities. MIS Quarterly, 30(2), 225-246.

Rodrigues, A., \& Malo, M. (2006). Estruturas de governança e empreendedorismo coletivo: o caso dos doutores da alegria. Revista de Administração Contemporânea, 10(3), 29-50. doi: $10.1590 / \mathrm{S} 1415-65552006000300003$ 
Ross, D. F. (2011). Introduction to supply chain management Technologies (2a ed.). Boca Raton: CRC Press.

Ross, A., \& Goulding, J. (2007). Supply chain transactional barriers to design cost management. Construction Innovation, 7(3), 274-287. doi: 10.1108/14714170710754759

Ruben, R., Boselie, D., \& Lu, H. (2007). Vegetables procurement by Asian supermarkets: a transaction cost approach. Supply Chain Management: an International Journal, 12(1), 60-68. doi: $10.1108 / 13598540710724365$

Silva, A. L. da, \& Fischmann, A. A. (1999). Impacto da tecnologia de informação no supply chain management: um estudo multicaso sobre a adoção de EDI entre varejo e indústria agroalimentar. Gestão e Produção, 6(3), 201-218. doi: 10.1590/S0104-530X1999000300006

Simsion, G. (2007). Data modeling: theory and practice. Melbourne: Technics Publications.

Subramani, M. (2004). How do suppliers benefit from information technology use in supply chain relationships? MIS Quarterly, 28(2), 45-73.

Terpend, R., Tyler, B. B., Krause, D. R., \& Handfield, R. B. (2008). Buyer-supplier relationships: derived value over two decades. Journal of Supply Chain Management, 44(2), 28-55. doi: 10.1111/j.1745-493X.2008.00053.x

Ulrich, D., \& Barney, J. B. (1984). Perspectives in organizations: resource dependence, efficiency, and population. The Academy of Management Review, 9(3), 471-481. doi: 10.2307/258287

Veen-Dirks, P. M. G. van, \& Verdaasdonk, P. J. A. (2009). The dynamic relation between management control and governance structure in a supply chain context. Supply Chain Management: An International Journal, 14(6), 466-478. doi: 10.1108/13598540910995237

Wathne, K. H., \& Heide, J. B. (2004). Relationship governance in a supply chain network. Journal of Marketing, 68(1), 73-89. doi: 10.1509/jmkg.68.1.73.24037

Webster, J., \& Watson, R.T. (2002). Analyzing the past to prepare for the future: writing a literature review. MIS Quarterly, 26(2), xiii-xxiii.

Whipple, J. S., Frankel, R., \& Anselmi, K. (1999). The effect of governance structure on performance: a case study of efficient consumer response. Journal of Business Logistics, 20(2), 43-62.

Williamson, O. E. (1979). Transaction-cost economics: the governance of contractual. Journal of Law and Economics, 22(2), 233-261.

Yin, R. K. (2009). Case study research - design and methods (4a ed.). London: SAGE Publications, Inc.

Yu, C. J., Liao, T., \& Lin, Z. (2006). Formal governance mechanisms, relational governance mechanisms, and transaction-specific investments in supplier-manufacturer relationships. Industrial Marketing Management, 35(2), 128-139. doi: 10.1016/j.indmarman.2005.01.004

Zhang, X., \& Aramyan, L. H. A. (2009). A conceptual framework for supply chain governance: an application to agri-food chains in China. China Agricultural Economic Review, 1(2), 136-154. doi: 10.1108/17561370910927408

Zhang, X., Donk, D. P. van, \& Vaart, T. van der (2011). Does ICT influence supply chain management and performance? a review of survey-based research. International Journal of Operations \& Production Management, 31(11), 1215-1247. doi: 10.1108/01443571111178501 